\title{
MENIMBANG TEOLOGI KAUM SUFI MENURUT AL-QUSYAIRI DALAM KITAB AL-RISĀLAH AL-QUSYAIRIYAH
}

\author{
Anisa Listiana \\ STAIN KUDUS \\ Anisa_Listiana@yahoo.com
}

\begin{abstract}
Abstrak
Teologi adalah disiplin yang menyangkut Tuhan (atau Realitas Ilahi) dan hubungan Tuhan dengan dunia. Dunia dan Allah adalah realitas yang berbeda. Dunia merupakan ciptaan sedangkan Allah adalah sang pencipta. Tulisan ini membahas tentang konsep teologi dalam ajaran tasawwuf Imam al-Qusyairi. Tasawuf yang dianut dan diajarkan oleh al-Qusyairi adalah tasawuf yang sejalan dengan ajaran syariat. Dari tulisan-tulisannya terlihat bahwa ia berupaya menyadarkan orang bahwa tasawuf yang benar adalah tasawuf yang bersandarkan pada akidah yang benar dan tidak menyalahi ketentuan syariat, seperti yang dianut oleh para salaf atau Ahl al-Sunnah,. Dalam perspektif alQusyairi, pemurnian tauhid sangatlah prinsip dan urgen, karena Islam dibangun di atas kekuatan tauhid, bahkan kekuatan Islam justru terletak pada fondasi tauhid. Apabila tauhid yang dimiliki oleh umat Islam kuat, maka agama Islam menjadi kuat dan tangguh. Tauhid adalah kekayaan yang terbesar yang dimiliki oleh umat Islam, sekaligus sebagai senjata yang ampuh dalam menghadapi berbagai rongrongan hawa nafsu.
\end{abstract}

abstract

THE THEOLOGY OF SUFISM OF AL-QUSHAYRI IN THE BOOK OF ALRISALAH AL-QUSYAIRIYAH: Theology is a discipline concerning God (or the Divine Reality) and the relationship of God with the world. World and God are different reality. The world is a creation of God while God is the creator. This paper discusses the concept of theology in the tasawwuf 
teachings of Imam al-Qushayri. The sufism espoused and taught by alQushayri is in line with the syari'ah. From his writings, it appears that he seeks to remind people that the true Sufism is Sufism which relies on the correct creed and does not violate the provisions of the syari'ah as adopted by the Salaf or Ahl al-Sunnah. In al-Qushayri's perspective, purification of tauhid (monotheism) is fundamental and urgent, because Islam is built on the strength of tauhid, even the power of Islam lies in the foundation of tauhid. If the tauhid owned by Muslims is strong, then Islam will be strong and tough. Tauhid is the greatest wealth owned by Muslims, as well as a powerful weapon in the face of undermining lust.

Kata Kunci : Teologi Kaum Sufi, Kitab Risalatul Qusyairiyah

\section{A. Pendahuluan}

Al-Qusyairi, lengkapnya Abu al-Qāsim Abd al-Karìm alQusyairi adalah sufi terkemuka dari abad ke-11 (5 H). Ia lahir pada 986 (376 H) di Istiwā, dekat dengan salah satu pusat pengajaran ilmu-ilmu agama, kota Nisyapur (di Iran). Sebelum menyelami dan mengamalkan ilmu tasawuf, terlebih dahulu ia mendalami fikih, ilmu kalam, usul fikih, sastra Arab, dan lain-lain. Ia belajar dan bergaul dengan banyak ulama, antara lain dengan Abu Bakar Muhammad bin Abu Bakar al-Ṭūsi (w. 1014/405 H), ahli fikih, dengan Abu Bakar bin Faurak (w. 1016/407 H), ahli usul fikih dan ilmu kalam, dengan Abu Ishāq al-Isfarayaini (w. 1027/418 H), dan lain-lain.

Setelah matang menyelami ilmu lahir, sehingga ia pantas disebut ahli fikih, yang menganut mazhab Syāfi'i, dan ahli ilmu kalam, yang menganut aliran Asy'ariyah atau Ahl al-Sunnah walJama'ah, ia melanjutkan studinya pada seorang sufi terkenal di Nisyapur yaitu Syekh Abu Ali ad-Daqqaq (w. 1023/412 H). Syekh ini mempunyai pengaruh yang besar atas pribadi al-Qusyairi, dan hasil membimbingnya menjadi bagian dari kelompok murid-murid yang istimewa (khawās). Al-Qusyairi bahkan dikawinkan dengan putri Syekh Ali ad-Daqqaq.

Dengan latar belakang kematangan dalam ilmu lahir(syariat), tidak mengherankan bahwa tasawuf yang dianut dan diajarkan oleh al-Qusyairi adalah tasawuf yang sejalan dengan ajaran syariat. Dari tulisan-tulisannya yang dijumpai, terlihat bahwa ia berupaya menyadarkan orang bahwa tasawuf yang benar itu adalah tasawuf yang bersandarkan pada akidah yang benar, seperti yang dianut 
oleh para salaf atau Ahl al-Sunnah, dan tidak menyalahi ketentuan syariat. ${ }^{1}$

Sebagai pengikut Tauhid Asy'ariyah, ia juga aktif membela akidah Ahl al-Sunnah wal-Jamaah, dan menyerang aliran-aliran lain, seperti Syi'ah, Mu'tazilah, dan lain-lain. Karena aktivitas demikian, ia pernah dipenjarakan pada 1055 (445 H), selama lebih sebulan, oleh pihak penguasa (Tugrul Bek), berdasarkan saran menterinya yang berpaham Syi'ah. Dua puluh tahun kemudian, ia wafat dan dikuburkan di Nisyapur (pada 1075/465 H).

Karya al-Qusyairi yang amat berharga bagi sejarah kesufian adalah karya tulisnya yang bernama al-Risālah al-Qusyairiyyah, karena dengan karya tulis tersebut ia telah berhasil mengabadikan warisan rohaniah kaum sufi abad ke-3 dan 4 Hijriyah, berupa keterangan-keterangan tentang perjalanan hidup dan wejanganwejangan para tokoh sufi. Karya tulisnya yang lain, yang cukup penting pula adalah Lațāif al-Isyārāt, sebuah kitab tafsìr al-Qur'an dengan penafsiran kesufian. Selain dari kedua karya tulis di atas (sudah dicetak), masih ada 13 buah judul lagi karya tulisnya, sebagian sudah diterbitkan dan yang lain masih berupa manuskrip (tulisan tangan). ${ }^{2}$

Dalam konsepnya tentang Tauhid, Al-Qusyairi membagi Tauhid dalam tiga kategori: Pertama, tauhid Allah untuk Allah, yakni mengetahui bahwa Allah itu Esa. Kedua, mengesakan Allah untuk makhluk, yaitu keputusan Allah bahwa seorang hamba adalah yang mengesakan-Nya dan Allah menciptakannya sebagai hamba yang mempunyai tauhid. Ketiga, tauhid makhluk untuk Allah, yaitu seorang hamba yang mengetahui bahwa Allah adalah Esa. Dia memutuskan sekaligus menyampaikan bahwa Allah itu Esa. Uraian ini merupakan penjelasan singkat tentang makna tauhid.

Menurutnya seorang hamba Allah yang telah bertauhid maka ia akan merasakan betapa nikmatnya bisa mengenal Tuhan. Dengan begitu manusia bisa mencapai ma'rifah Allāh sebagai ma'rifah sejati.

${ }^{1}$ Tim Penulis IAIN Syarif Hidayatullah, Ensiklopedi Islam Indonesia, (Jakarta: Djambatan, 1992), h. 796-798.

${ }^{2} \mathrm{Abu}$ al-Qāsim Abd al-Karīm Hawāzin al-Qusyairi an-Naisaburi, al-Risālah alQusyairiyah, disadur Umar Faruq, (Jakarta: Pustaka Amani, 2002), h. 4. 
Namun tauhid yang demikian hanya bisa dicapai melalui itikad yang bersih tanpa ada lagi rasa ketergantungan dirinya dengan selain Allah. Esensi (inti) Tauhid adalah penyerahan diri secara mutlak kepada khāliq dengan keyakinan tinggi terhadap keberadaan zat yang tak bisa diserupakan dengan makhluk. Tauhid seperti ini akan menimbulkan gairah bagi seorang hamba untuk berbakti terhadap segala perintah dan larangan Allah. Ketenaran Al-Qusyairi yang demikian itulah yang akan dikaji atau ditimbang dari perspektif lain tentang teologi sufi dalam tulisan ini.

Al-Qusyairi adalah seorang ulama terkenal yang menguasai berbagai bidang ilmu, namun jiwa kesufiannya lebih menonjol dan sangat dominan. Karyanya banyak mengupas masalah tasawuf dan ilmu-ilmu Islam.

\section{B. Menimbang Pemikiran Teologi Sufi Al-Qusyairi}

Menurut al-Qusyairi para guru sufi dalam mendekatkan diri kepada Allah selalu berpegang teguh pada tauhid dan tidak pernah bercampur dengan bid'ah. Mereka benar-benar menjaga kemurnian tauhid tidak sebagaimana anggapan sementara pihak yang menganggap kaum sufi telah menyebarkan ajaran sesat. Hal ini sebagaimana dipaparkan dalam buku al-Risālah alQusyairiyah:

"Sesungguhnya para guru kaum sufi telah membangun kaidahkaidah ajaran sufi yang didasarkan atas prinsip ketauhidan yang benar. Mereka menjaganya dari bid'ah; mendekatkannya dengan sesuatu yang mereka dapatkan dari para salaf (satu istilah pengelompokan umat secara periodik yang merujuk pada golongan terdahulu, yaitu generasi para tābi'in yang mengikuti jejak para pendahulunya) dan Ahl al-Sunnah (Rasulullah saw. dan para sahabat), ajarannya tidak didapati unsur-unsur penyerupaan pada Al-Haqq (panteisme) dan peniadaan (ateisme). Mereka mendefinisikan segala sesuatu dengan penyandaran kepemilikan tunggal kepada Haqq alQadam (alam yang baru adalah kepunyaan Zat Yang Terdahulu); menyatakan sesuatu yang ada dengan sifat ketiadaan (ada yang bersifat nisbi). Oleh karena itu, seorang guru sufi terbesar, Imam Al-Junaid, semoga Allah selalu merahmatinya, berkata, Tauhid adalah pengesaan pada Yang Lama dari yang baru. Beberapa ketentuan dasar hukum tentang akidah oleh 
sejumlah pembesar kaum sufi telah digariskan berdasarkan dalil-dalil yang jelas dan kesaksian-kesaksian yang tampak."

\section{a. Ma'rifah Allāh}

Imam al-Qusyairi dengan mengutip Imam al-Junaid berkata: "Sesungguhnya awal yang dibutuhkan oleh seorang hamba dari sesuatu yang bersifat hikmah adalah mengetahui Sang Pencipta atas keterciptaan dirinya; kebaruan diri tentang bagaimana kebaruannya; sifat keperbedaan Sang Pencipta dari sifat makhluk; sifat keperbedaan "Zat Yang Lama” dari "yang baru” (alam); menurut pada ajakan-Nya; dan mengetahui keharusan diri untuk bertaat kepada-Nya. Sesungguhnya orang yang belum mengetahui Zat Sang Penguasa alam, maka ia tidak akan mengetahui keberadaan kerajaan alam tentang status kepemilikannya untuk siapa." Selanjutnya Imam al-Qusyairi dengan mengutip pandangan Abu T ayyib Al-Maragi mengatakan, setiap unsur dalam diri seorang hamba memiliki fungsi yang berbeda-beda berkaitan dengan ke-ma'rifahannya kepada Allah. Akal, menurutnya, memiliki fungsi pembuktian dalil secara logika, hikmah memberi isyarat, dan ma'rifah memberi kesaksian secara utuh. Akal menunjukan, hikmah mengisyaratkan, dan ma'rifah mempersaksikan. Karena itu, kejernihan ibadah tidak akan diperoleh kecuali dengan kejernihan tauhid. Kata Imam AlJunaid, tauhid berarti pengesaan Zat Yang Esa dengan hakikat dan kesempurnaan keesaan-Nya. Sesungguhnya Dia Zat Yang Esa yang tidak beranak dan tidak diperanakkan. Pengesaan-Nya juga dengan peniadaan terhadap sesuatu yang berlawanan, kesamaan, dan keserupaan. Esa tanpa penyerupaan, pembagaimanaan, penggambaran, pengasosiaan, dan penyimbolan. Tak satu pun di semesta alam ini yang menyamai-Nya. Dia adalah Zat Yang Maha Mendengar dan Melihat. ${ }^{4}$

Dari pernyataan di atas menunjukkan bahwa dalam pandangan Imam al-Qusyairi bahwa ma'rifah Allāh merupakan kunci utama untuk memperkuat fondasi akidah seseorang. Tanpa berupaya ma'rifah Allāh maka orang akan dengan mudah bergeser tauhid atau teologinya. Karenanya ma'rifah Allāh

${ }^{3}$ Ibid., h. 39.

4lbid., h. 40-41. 
merupakan awal bagi seorang hamba untuk mendapat dan menemukan dirinya.

Menurut Imam al-Qusyairi sebagaimana dikutif Mustafa Zahri, arti ma'rifah menurut pendapat ulama (bukan ahli tasawuf) ialah pengetahuan, maka tiap-tiap ilmu itu adalah ma'rifah dan tiaptiap ma'rifah adalah ilmu, dan tiap-tiap orang alim tentang Allah, adalah orang arif dan tiap-tiap orang arif adalah alim. Barang siapa yang mengenal Allah dengan jalan pertolongan Allah maka orang itu adalah arif tentang Allah secara hakekat (ahli tasawuf). Orang yang arif tentang Allah dengan cara dalil saja maka itu, adalah orang mutakallimin (ahli Ushuluddin). Orang yang arif tentang Allah dengan cara taklid (menuruti perkataan orang tanpa mencari dalil) maka orang itu adalah orang awam/orang bodoh. ${ }^{5}$

Arti ma'rifah adalah mengetahui Allah dari dekat, di mana hati sanubari melihat Allah. ${ }^{6}$ Ma'rifah dari segi bahasa berasal dari kata 'arafa, ya'rifu, irfan, ma'rifah, yang artinya pengetahuan atau pengalaman. Ma'rifah dapat pula berarti pengetahuan rahasia hakikat agama, yaitu ilmu yang lebih tinggi dari pada ilmu yang didapat oleh orang-orang pada umumnya. ${ }^{7}$

Ma'rifah bukanlah hasil pemikiran manusia tetapi bergantung kepada kehendak dan rahmat Tuhan. Ma'rifah adalah pemberian Tuhan kepada sufi yang sanggup menerimanya.

Alat untuk memperoleh ma'rifah, oleh kaum sufi disebut sir. Menurut al-Qusyairi ada tiga alat dalam tubuh manusia yang dipergunakan sufi dalam hubungan mereka dengan Tuhan. Qalb, untuk mengetahui sifat-sifat Tuhan, ruh untuk mencintai Tuhan, dan sir untuk melihat Tuhan. Sir lebih halus dari ruh, dan ruh lebih halus dari qalb. Qalb tidak sama dengan jantung atau heart dalam bahasa Inggris, karena qalb, selain dari alat untuk merasa adalah juga alat untuk berpikir.

Perbedaan qalb dengan 'aql, ialah bahwa 'aql tak bisa memperoleh pengetahuan yang sebenarnya tentang Tuhan, sedang

${ }^{5}$ Mustafa Zahri, Kunci Memahami Tasawuf, (Surabaya: PT. Bina Ilmu, 1998), h. 170-171.

${ }^{6}$ Ibid., h. 37.

${ }^{7}$ M.Solihin, Tasawuf Tematik Membedah Tema-Tema Penting Tasawuf, (Bandung: Pustaka Setia, 2003), h. 41. 
qalb bisa mengetahui hakikat dari segala yang ada, dan jika dilimpahi cahaya Tuhan, bisa mengetahui rahasia-rahasia Tuhan. Kelihatannya $\overline{s i r}$ bertempat di ruh dan ruh bertempat di qalb dan sir timbul dan dapat menerima iluminasi dari Allah kalau qalb dan ruh telah suci sesuci-sucinya dan kosong sekosong-kosongnya, tidak berisi apapun. Di waktu itulah Tuhan menurunkan cahaya-Nya kepada sang sufi dan yang dilihat oleh sufi itu pun hanyalah Allah. Di sini sampailah ia ke tingkat ma'rifah. Memperoleh ma'rifah merupakan proses yang bersifat kontinyu.

Makin banyak seorang sufi memperoleh ma'rifah dari Tuhan, makin banyak yang diketahuinya tentang rahasia-rahasia Tuhan, dan ia pun makin dekat kepada Tuhan. Tetapi memperoleh ma'rifah yang penuh tentang Tuhan, tidak mungkin karena manusia bersifat finite, sedang Tuhan bersifat infinite.

b. Sifat-sifat Tuhan

Secara garis besarnya, Tuhan itu bersifat dengan segala sifat: kesempurnaan, dan Maha Suci dari segala sifat kekurangan. Sifatsifat Tuhan dapat dibagi menjadi 3 macam sifat, yaitu; (1) sifat wājib, (2) sifat Mustahil, dan (3) sifat Jäiz. Sifat wajib ialah sifat yang pasti dimiliki oleh Tuhan, mustahil tidak dimiliki oleh-Nya. Ulama-ulama Ilmu Tauhid merumuskan, sifat-wajib bagi Allah ada 13 banyaknya, sebagai tersebut di bawah ini:

1. Wujūd artinya, Allah itu ada. Mustahil bila Allah tidak ada. Adanya Allah terjadi sebab zatnya sendiri, tidak karena diadakan oleh sebab lain di luar zat-Nya. Bukti-bukti tentang adanya Allah, telah diterangkan di muka dengan dalil-dalil fisika, akhlak, kesaksian, inayah dan dalil ikhtira'.

2. Qidim artinya, Allah itu azali atau dahulu. Dahulunya Allah tidak berpermulaan, sebab sesuatu yang mempunyai permulaan berarti sesuatu itu baharu dan sesuatu yang baharu tentulah dijadikan oleh sesuatu yang lain di luar dirinya. Dus, makhluk namanya. Tentu saja keadaan yang demikian mustahil bagi Allah.

3. Baqà' artinya. Allah itu kekal abadi. Allah ada untuk selamalamanya, tidak mengalami kebinasaan atau kehancuran, tidak mempunyai akhir kesudahan. Sesuatu yang dapat binasa dan punya akhir, pastilah bukan Tuhan tetapi mahluk namanya.

4. Mukhalafah li al-hawädis artinya, Allah itu berbeda dengan segala yang baru. Yang baharu ialah mahluk. Jadi Tuhan berbeda 
dengan mahluk. Perbedaan di sini meliputi segala hal, baik mengenai zat, sifat, maupun perbuatan. Tidak mungkin terjadi persamaan, antara Tuhan Sang Pencipta dengan mahluk yang diciptakan.

5. Qiyām Bi nafsih artinya, Allah itu berdiri sendiri atau "mandireng pribadi" Allah ada dan berbuat dengan kekuatan dirinya sendiri. Wujud Allah ditentukan oleh dirinya sendiri, bukan oleh yang lain di luar dirinya. Dia tidak memerlukan sesuatu bantuan di luar Zat-Nya, sebab memerlukan bantuan berarti lemah, dan yang lemah adalah mahluk namanya, bukan Tuhan.

6. Wahdaniyah artinya, Allah itu Maha Esa. Kemaha-Esaan Allah meliputi Zat-Nya, Sifat-Nya dan perbuatan-Nya seperti yang telah diterangkan di muka. Khusus tentang Esa dalam perbuatan (AlWahdatu Fil-Af'al) perlu ditambahkan, bahwa artinya ialah, Tuhan menyendiri dalam berbuat, tidak ada sekutu bagi-Nya. Perbuatanperbuatan yang dikerjakannya semata-mata terjadi atas dasar kehendak dan kekuasaan-Nya yang absolut, tanpa ada campur tangan pihak kain. Dia adalah satu-satunya Allah Sang Maha Pencipta dalam arti yang sebenar-benarnya, yang tidak disamai oleh siapapun atau apapun.

7. Qudrah artinya, Allah itu berkuasa. Berkuasa berbuat apa saja dan menguasai segala apa saja. Kekuasaan Tuhan bersifat penuh, mutlak, absolut, dalam arti sebenar-benarnya. Mustahil Tuhan tidak berkuasa sebab tidak berkuasa berarti lemah, dan yang lemah bukan Tuhan.

8. Irādah artinya Allah itu berkehendak. Allah dalam berbuat apa saja, berbuat atas dasar kehendak-Nya atau kemauan-Nya. Sementara itu segala sesuatu bisa terjadi bilamana dikehendaki oleh-Nya. Dengan adanya Allah berkehendak, maka setiap la berbuat mustilah berbuat dengan sengaja, menurut suatu rencana yang telah ditentukan. Selain itu perbuatan Tuhan mustilah dikerjakan. Allah juga tidak mungkin berbuat karena terpaksa, sebab berbuat karena terpaksa berarti lemah, dan yang lemah bukan Tuhan.

9. 'Tlmu artinya, Allah itu mengetahui. Pengetahuan Tuhan meliputi segala suatu dari yang sebesar-besarnya sampai yang sekecilkecilnya, baik yang telah atau akan terjadi, di bumi, di udara, 
di laut dan di mana saja, di dalam gelap atau terang, lahir atau batin.

10. Hayah, artinya, Allah itu hidup. Hidup Allah kekal abadi, tidak ada waktu lahir dan tidak ada waktu matinya. la hidup selamalamanya, dengan tidak berkesudahan. Mustahil Allah tidak hidup, karena tidak hidup berarti mati. Yang mati tidak bisa berbuat apa-apa.

11. Samā' artinya, Allah itu mendengar. Pendengaran Allah meliputi segala suara yang ada dimanapun, baik suara yang keras maupun perlahan. Tidak mungkin Tuhan tuli, sebab tuli adalah satu sifat kekurangan yang mustahil ada pada Allah.

12. Bashār artinya, Allah itu melihat. Penglihatan Tuhan meliputi apa saja, yang berada di mana saja dan dalam keadaan bagaimana saja. Mustahil Allah buta, sebab buta adalah satu sifat kekurangan yang tidak pantas ada pada Allah Yang Maha Sempurna.

13. Kalām artinya, Allah itu berkata-kata. Tapi berkata-katanya Allah berbeda dengan berkata-katanya manusia atau mahluk lainnya.

Tiga belas sifat ini oleh sementara Ulama Tauhid ditambah lagi dengan tujuh Sifat, sehingga Sifat Wajib bagi Allah seluruhnya berjumlah dua puluh. Tujuh sifat tersebut ialah:

14. Qādiran artinya maha selalu berkuasa.

15. Muridan artinya maha selalu berkehendak.

16. 'Aliman artinya maha selalu mengetahui.

17. Hayyan artinya maha selalu hidup.

18. Sami'an artinya maha selalu mendengar.

19. Bașiran artinya maha selalu melihat.

20. Mutakalliman artinya maha selalu berkata-kata. ${ }^{8}$

${ }^{8}$ Kalau diperhatikan, 7 sifat terakhir ini sebenarnya masing-masingnya hanyalah merupakan kelaziman belaka dari sifat-sifat wajib bagi Allah angka 7 sampai dengan 13, yaitu Qudrah, Irādah,'Пtmu, Hayah, Samā', Bashār dan Kalām. Sifat Qädiran adalah kelaziman dari sifat Qudrah; Murīdan adalah kelaziman dari Irādah, dan begitu seterusnya. Oleh karenanya sementara Ulama memandang 7 sifat kelaziman ini tidak perlu disebutkan dan diperhitungkan tersendiri, sebab sudah dengan sendirinya 7 sifat tersebut masing-masingnya terkandung dalam sifat Qudrah, Irādah,'Tlmu, Hayah dan seterusnya. Karenanya menurut golongan Ulama ini. Sifat-wajib bagi Allah ada 13, tidak 20. Yang mengadakan tambahan 7 sifat 
Pembagian sifat-sifat Wajib. Sifat-sifat Wajib bagi Allah dapat dibagi menjadi 4 bagian, yaitu:

1) Sifat Nafsiyah, terdiri dari satu sifat ialah: Wujū d, Sifat Nafsiyah berarti sifat diri, suatu sifat yang tidak bisa dipisahkan dari zatnya.

2) Sifat Salbiyah, terdiri dari 5 sifat yaitu Qidām, Baqa', Mukhalafah li al-Hawādis, Qiyām bi nafsih dan Wah-daniyah.

3) Sifat Salbiyah artinya sifat yang meniadakan, oleh karenanya, maka Qidām meniadakan adanya permulaan bagi Allah, Baqa' meniadakan adanya kesudahan bagi Allah dan seterusnya.

4) Sifat Ma'āni, terdiri dari 7 sifat yaitu: Qudrah, Irādah,'Tlmu, $H$ ayah, Samā', Bașār dan Kalām.

Arti sifat Ma'àni ialah Sifat Makna. Disebut demikian sebab sifat-sifat itu mempunyai makna yang menetap pada Zatnya. Sifat Ma'ani ini berbeda dengan sifat Salbiyah, dan perbedaannya terletak, kalau Sifat Salbiyah hanya ada dalam sebutan saja, sedang Sifat ma'āni ialah sifat yang betul-betul ada pada Zatnya.

Sifat Ma'nawiyah, yaitu sifat yang merupakan kelaziman dan Sifat Ma'ani. Dan karena Sifat Ma'āni ada 7, maka Sifat Ma'nawiyahpun juga 7, yaitu; Qādiran, Murìidan, 'Āliman, Hayyan,Sami'an, Bașiran, Mutakalliman. Seperti telah disebutkan di muka, pendapat adanya Sifat Ma'nawiyah ini berasal dari Abu Mansyūr Al-Maturidi, tetapi tidak disetujui oleh Abu al-H \}asan al-Asy'āri.

Disamping sifat-sifat wajib di atas, terdapat juga sifat Jāiz bagi Allah. Sifat Jāiz tersebut hanya ada satu sifat, yaitu bebasnya Allah berbuat atau tidak berbuat sesuatu. Jāiz artinya "yang boleh". Jadi Tuhan boleh berbuat sesuatu dan boleh juga tidak berbuat sesuatu.

Berbuat atau tidak berbuat, menjadi wewenang sepenuhnya bagi Tuhan untuk menentukannya sendiri. Allah adalah bebas dan merdeka. Bagi Tuhan menjadikan alam ini tidak wajib, tetapi semata-mata boleh saja hukumnya. ${ }^{9}$

kelaziman tersebut ialah Abu Mansyūr al-Maturidi, seorang tokoh ulama Tauhid dari Mazhab Hanafi. Sedang yang menolaknya ialah Abu al-Ḥasan al-Asy’āri, seorang tokoh ulama Tauhid dari Mazhab Syāfi'i

${ }^{9}$ Humaidi Tatapangarsa, Kuliah Aqidah (Surabaya: Bina Ilmu, 1990), h. 63. 
c. Iman

Dalam al-Risālah al-Qusyairiyah dikatakan Iman menurut Abu Abdullah bin Khafif adalah pembenaran hati terhadap sesuatu yang telah dijelaskan oleh Al-Haqq tentang masalah-masalah gaib. ${ }^{10}$

Iman menurut pengertian bahasa Arab ialah at-tașdiqu bi al-qalbi, membenarkan dengan (dalam) hati. Ibn Katsir menunjuk beberapa ayat al-Qur'an yang memberi pengertian bahwa iman ialah pengakuan dengan (dalam) hati, antara lain: (QS. At-Taubah (9) : 61). Dia membenarkan Allah dan membenarkan orang-orang mukmin. Pernyataan saudara-saudara Yūsuf kepada Ya'qūb (QS. Yusuf (12): 17): 'Dan engkau ayah sekali-kali tidak akan membenarkan kami. (Q.S. al-'Așr (103): 3) 'Melainkan mereka yang membenarkan dalam hati dan mengerjakan amalan saleh.'

Adapun pengertianiman menurutsyara', ialah "mengucapkan dengan lidah, membenarkan dengan hati dan mengerjakan dengan anggota tubuh". Rumusan iman menurut syara' dalam ungkapan Ibn Katsir, tertulis: Iman syar'i tidak lain dari pengakuan hati, ikrar lidah dan amalan anggota tubuh. Tegasnya iman menurut batasan syara' ialah memadukan ucapan dengan pengakuan hati dan perilaku. Dengan lain perkataan mengikrarkan dengan lidah akan kebenaran Islam, membenarkan yang diikrarkan itu dengan hati dan tercermin dalam perilaku hidup sehari-hari dalam bentuk amal perbuatan, atau dengan ibarat yang lain dapat pula dirumuskan bahwa iman, ialah: Iman itu ialah tunduk ruh kepada kebenaran serta khudu' kepadanya.

Tunduk dan khudu' ruh kepada Yang Haq (Allah). Hati tidak akan tundukjika belum berkumpul:(1)membenarkan dengan hati (taș diq qalbi), (2) mengikrarkan dengan lidah; dan (3) mengamalkannya. Karena itu al-Isbahani mengatakan, bahwa menurut mazhab Ahl al-Sunnah, iman dapat bertambah dan berkurang. Maka apakah seseorang yang membenarkan dengan hati tetapi tidak terlihat pada perilaku hidup bisa dinamakan mukmin mutlak? Menurut pendapat yang kuat tidak bisa, sebab dia tidak melaksanakan apa yang seharusnya diperbuat selaku seorang yang beriman. ${ }^{11}$

${ }^{10}$ Al-Naisaburi, al-Risālah..., h. 43.

${ }^{11}$ T.M.Hasbi Ash Shiddiqy, Al-Islam, jld. ke-1, (Jakarta: Bulan Bintang, 1971), h.17-18. 
d. Kufur

Dalam al-Risālah al-Qusyairiyah dipaparkan:

"Seorang ulama besar, al-Wāsiți suatu saat ditanya tentang arti kufur pada Allah. Ia menjawab bahwa kufur dan iman, dunia dan akhirat adalah dari, menuju, dengan, dan bagi Allah. Dari Allah segala permulaan dan susunan; kepada-Nya tempat kembali dan berakhir; bersama-Nya sesuatu yang tetap dan lenyap; dan bagi-Nya semua kerajaan dan ciptaan." ${ }^{12}$

Kufur berarti mengingkari suatu bagian dari ajaran Islam di mana tanpa bagian itu keislaman seseorang menjadi batal atau tidak sempurna. Maka mengingkari makna syahadat adalah kufur. Mengingkari bagian penting ajaran Islam yang diharamkan, seperti salat adalah kufur. Mengingkari salah satu hukum pidana Islam, seperti hukum bagi pencuri, pezina dan lainnya adalah kufur.

Kufur itu ada dua jenis: Pertama, kufur besar yaitu mengingkari bagian tertentu dari Islam yang tanpa bagian itu keislaman seseorang menjadi batal. Kedua, kufur kecil yaitu mengingkari bagian tertentu dari Islam yang tanpa bagian itu keislaman seseorang menjadi tidak sempurna.

Perbedaan antara kedua jenis kufur itu sebagai berikut: Pertama, kufur besar membatalkan amal. Sedang kufur kecil tidak sampai membatalkan amal. Kedua, kufur besar menyebabkan keabadian dalamneraka.Sedangkankufurkeciltidakmengharuskan pelakunya masuk neraka. Mereka, menurut satu pendapat, diserahkan kepada kehendak Allah, boleh disiksa boleh diampuni menurut kehendak Allah. Menurut pendapat lain, mengharuskan pelakunya masuk neraka selamanya. Tetapi kedua pendapat itu sepakat bahwa kufur kecil menyebabkan pelakunya mendapatkan ancaman siksaan dari Allah swt. ${ }^{13}$ Ketiga, jika seseorang mati dalam keadaan masih kufur besar maka ia tidak akan diampuni, sedang jika ia mati dalam keadaan kufur kecil maka ia diserahkan kepada kehendak Allah, boleh diampuni atau disiksa, terserah kepada kehendak Allah swt.

${ }^{12}$ Al-Naisaburi, al-Risālah..., h. 44-45.

${ }^{13}$ Ibrahim Muhammad bin Abdullah al-Buraikan, Pengantar Studi Aqidah Islam, alih bahasa, Muhammad Anis Matta, (Jakarta: Robbani Press, 1998), h. 278283. 


\section{e. "Arasy}

Dalam Al-Risāah al-Qusyairiyah, Zun Nūn Al-Mișri pernah ditanya seseorang tentang ayat yang artinya: Tuhan Yang Maha Pemurah, Yang bersemayam diatas "Arasy."(QS. Thaha (20):5). Lalu dijawab, "Zat-Nya tetap, tempat-Nya tidak ada, sebab Dia ada dengan zat-Nya; sedang segala sesuatu ada dengan hukum-Nya menurut kehendak-Nya. Sedangkan menurut Asy-Syibli firman itu bermakna: Ar-Rahman bersifat kesenantiasaan (tidak bergeser), Al'Arasy (singgasana-Nya) bersifat baru, dan 'Arasy pada al-Rahmān bersemayam. Adapun Ja'far bin Nașr mengartikannya bahwa ilmu-Nya menyeluruh dengan segala sesuatu. Karena itu, tak ada sesuatu yang lebih dekat kepada-Nya dari sesuatu yang lain. Ja'far aṣ-Ṣādiq berkata, "Barangsiapa yang meyakini bahwa Allah dalam, dari, dan di atas sesuatu, maka dia telah berbuat syirik. Karena, jika Dia berada dalam sesuatu, niscaya Dia terkurung; jika dari sesuatu, maka Dia baru (tercipta); dan jika di atas sesuatu, berarti Dia terpikul. ${ }^{14}$

Dalamal-Qur'andisebutkan:"AllahYangMahaPemurahbertahta di atas "Arasy."(Q.S. Taha (20):5). Dalam ayat ini disebutkan bahwa Allah bertahta diatas 'Arasy. Ayat ini termasuk ayat mutasyabihat. Sebagaimana telah kita pelajari dalam bab sebelumnya bahwa Ulama Salaf mengartikan istiwā (istawā) dengan bersemayam atau bertahta menurut zahirnya ayat, sedangkan bagaimana hakekat yang sebenarnya kita manusia tidak dapat mengetahuinya, kita kembalikan kepada Allah sendiri, tegasnya hanya Allah sendirilah yang mengetahui hakekat dari bertahta itu. Dan sudah jelas bahwa bertahta Tuhan berbeda dengan bertahtanya makhluk.

Sementara itu ulama Khalaf mengartikan istawā dengan berkuasa. Jadi Allah berkuasa di atas 'Arasy. Adapun 'Arasy menurut sebagian ulama ialah suatu benda yang maha besar yang menjadi pusat markas seluruh alam mengatur perjalanan dunia seluruhnya. "Dan sebagaimana hakekat wujud 'Arasy itu hanya Allah sendiri yang Maha Mengerti. “

Imam Malik berkata istiwā (bertahta) itu sudah ma'lūm diketahui, sedangkan caranya bagaimana majh $\bar{\imath} l$ yakni tidak dapat

${ }^{14}$ Al-Naisaburi, Al-Risālah..., h. 47-48. 
kita ketahui. Menurut sebagian ulama bahwa kata-kata 'Arasy harus ditakwili, dibelokkan dari arti zahirnya kepada arti lain sesuai ilmu bahasa (termasuk majāz) agar tidak menjadi salah faham, ialah diartikan dengan singgasana. Jadi Allah bertahta diatas singgasanaNya yakni Allah Maha Kuasa dalam segala hal apa saja.

'Arasy menurut istilah bahasa artinya singgasana raja, yang dimaksud dengan bersemayam ialah yang sesuai dengan kebesaran Allah dan kesucian-Nya. ${ }^{15}$ Pernah ditanya kepada Malik tentang makna istawa ' = bersemayam, berketetapan. Maka beliau menjawab: "Menurut lughat istawā itu terang, Betapa Tuhan bersemayam atas 'Arasy itu, tak dapat kita ketahui. Menanyakan tentang bagaimana Tuhan bersemayam di atas 'Arasy adalah bid'ah. Demikianlah pendapat sahabat dan ulama salaf. Dan ulama salaf menerima hal tersebut dengan tidak menerangkan begini dan begitu dan tidak menyerupakan keadaan itu dengan keadaan makhluk. Mereka menyerahkan hal itu kepada Allah sendiri. Adapun Asy'ariyah mentakwilkan makna ini bahwa sesudah Allah membentuk langit dan bumi, Allah pun mentadbirkan segala urusannya dan menentukan nizhamnya menurut takdir dan hikmah yang telah ditentukan. ${ }^{16}$

\section{f. Allah Yang Hak}

Dalam al-Risālah al-Qusyairiyah dikemukakan:

"Dia sesungguhnya Esa dalam zat-Nya; tidak juga Dia menyerupai makhluk-Nya. Dia tidak berjasad, beraga, berjiwa, tak ada sifat-sifat yang lembut, tak tergambarkan dalam hayal, tidak terukur dalam yang masuk akal, tidak berarah dan bertempat; tidak ada waktu dan zaman yang menjalankannya; dan tidak boleh dalam pensifatan-Nya mengurangi dan menambah. Tidak ada bentuk dan ukuran yang mencirikanNya; tidak ada akhir dan batas yang memutuskan-Nya; tak ada kejadian yang menindih-Nya; tidak ada motivator yang membawa-Nya pada perbuatan; tak ada warna dan keberadaan yang boleh mewarnai-Nya; dan tak ada perpanjangan dan

${ }^{15}$ Imam Jamal al-Din al-Mahalli, dan Imam Jamaluddin as-Suyuti, Tafsir Jalālain, terj. Bahrun Abu Bakar, (Bandung: Sinar Baru al-Gesindo, 2003), h. 608.

${ }^{16}$ T.M Hasbi Ash Shiddieqy, Tafsir al-Qur'anul Madjied "an-Nur”, (Jakarta: Bulan Bintang, 1970), h. 1364. 
bantuan yang menolong-Nya. Sesuatu yang telah ditentukan tidak bisa keluar dari ketentuan-Nya; yang tercipta tidak bisa terlepas dari hukum-Nya; bagaimana dan apa yang dibuat oleh-Nya tidak tercela. Allah juga tidak boleh dikatakan "di mana dan bagaimana Dia”. Keberadaan-Nya tidak dimulai; tidakjuga bisa ditanyakan kapan keberadaan-Nya. Sifat kekalNya tidak berakhir. Karena itu, Dia dikatakan sebagai zat yang menyempurnakan ajal dan zaman, dan tidak boleh dikatakan mengapa Dia berbuat dan apa yang diperbuat, karena semua perbuatan-Nya tidak mempunyai sebab atau alasan." ${ }^{17}$

Bahwasanya Tuhan itu berbeda dengan semua makhluk. Artinya tidak ada satu makhluk pun yang menyamai Tuhan, baik di dalam zat-Nya, sifat-Nya, nama-Nya, maupun perbuatan-Nya.

\section{Penutup}

Berdasar uraian di atas, maka dapat diambil kesimpulan bahwa sesungguhnya para guru kaum sufi telah membangun kaidah-kaidah ajaran sufi yang didasarkan atas prinsip ketauhidan yang benar. Mereka menjaganya dari bid'ah; mendekatkannya dengan sesuatu yang mereka dapatkan dari para salaf (satu istilah pengelompokan umat secara periodik yang merujuk pada golongan terdahulu, yaitu generasi para tabiin yang mengikuti jejak para pendahulunya) dan ahli sunnah (Rasulullah saw. dan para sahabat), ajarannya tidak didapati unsur-unsur penyerupaan pada Al-Haqq (panteisme) dan peniadaan (ateisme). Mereka mendefinisikan segala sesuatu dengan penyandaran kepemilikan tunggal kepada Haqq al-Qadam (alam yang baru adalah kepunyaan Zat Yang Terdahulu); menyatakan sesuatu yang ada dengan sifat ketiadaan (ada yang bersifat nisbi). Oleh karena itu, seorang guru sufi terbesar, Imam AlJunaid, semoga Allah selalu merahmatinya, berkata, Tauhid adalah pengesaan pada Yang Lama dari Yang Baru. Beberapa ketentuan dasar hukum tentang akidah oleh sejumlah pembesar kaum sufi telah digariskan berdasarkan dalil-dalil yang jelas dan kesaksiankesaksian yang tampak.

Menurut al-Qusyairi para guru sufi dalam mendekatkan diri kepada Allah selalu berpegang teguh pada tauhid dan tidak

${ }^{17}$ al-Naisaburi, Al-Risālah..., h. 48-49. 
pernah bercampur dengan bid'ah. Mereka benar-benar menjaga kemurnian tauhid tidak sebagaimana anggapan sementara pihak yang menganggap kaum sufi telah menyebarkan ajaran sesat. Dalam perspektif al-Qusyairi, pemurnian tauhid sangatlah prinsipil dan urgen, karena Islam itu dibangun di atas kekuatan tauhid, bahkan kekuatan Islam adalah tauhid. Oleh karena itu, apabila tauhid yang dimiliki oleh umat Islam kuat, maka agama Islam menjadi kuat dan tangguh, namun bila tauhid yang dimilikinya lemah, maka Islam dipastikan akan lemah. Tauhid adalah kekayaan yang terbesar yang dimiliki oleh umat Islam, sekaligus sebagai senjata yang ampuh dalam menghadapi berbagai rongrongan hawa nafsu.[ ]

\section{Daftar Pustaka}

Ibrahim Muhammad bin Abdullah al-Buraikan, Pengantar Studi Aqidah Islam, alih bahasa, Muhammad Anis Matta, Jakarta: Robbani Press, 1998.

al-Mahalli, Imam Jamaluddin \& as-Suyūți, Imam Jamal ad-Din, Tafsir Jalālain, terj. Bahrun Abu Bakar, Bandung: Sinar Baru al-Gesindo, 2003.

an-Naisabūri, Abul Qasim Abdul Karim Hawāzin al-Qusyairi, AlRisālah al-Qusyairiyah , Jakarta: Pustaka Amani 2002.

Ash-Shiddiqy, T.M. Hasbi, Al-Islam, jilid 1, Jakarta: Bulan Bintang, 1971.

_, Tafsir al-Qur'anul Madjied “an-Nur”, Jakarta: Bulan Bintang, 1970.

Solihin, S., Tasawuf Tematik Membedah Tema-Tema Penting Tasawuf, Bandung: Pustaka Setia, 2003.

Tatapangarsa, Humaidi, Kuliah Aqidah, Surabaya : Bina Ilmu, 1990.

Tim Penulis IAIN Syarif Hidayatullah, Ensiklopedi Islam Indonesia, Jakarta: Djambatan, 1992.

Zahri, Mustafa, Kunci Memahami Tasawuf, Surabaya: PT. Bina Ilmu, 1998.

, Ma'rifah Allāh wa Ma'rifah al-Rasul, Surabaya: PT.Bina Ilmu, 2003. 